Jurnal Pena Sains Vol. 5, No. 2, Oktober 2018

p-ISSN: 2407-2311

e-ISSN: 2527-7634

\title{
THE ANALYZING OF CRITICAL THINKING SKILLS ON STUDENTS OF HIGH SHOOLS GRADE X IN PLAJU AND SEBERANG ULU II DISTRICT
}

\author{
Elsa Rinela Putri ${ }^{1 a}$, Saleh Hidayat ${ }^{2 b}$ dan Binar Azwar Anas Harfian ${ }^{3 c}$ \\ ${ }^{1,2,3}$ FKIP Universitas Muhammadiyah Palembang \\ Palembang, 30263, Indonesia \\ aelsarinela_p@yahoo.com, ${ }^{b}$ salehhidayat29@gmail.com, ${ }^{c}$ binar.azwar@gmail.com
}

Accepted: Sept 27, 2018 Published: October 31, 2018

\begin{abstract}
Based on the teacher questionnaire statement in Plaju and Seberang Ulu II District, the teacher has measured critical thinking skills. The teacher interview results stated that students still did not master the critical thinking skills of Biology High School. The purpose of this study was to determine the percentage level of mastery of critical thinking skills of class $X$ high school students in Plaju and Seberang Ulu II District. This research is a quantitative descriptive research; the sample used is a public high school representing the District of Plaju and Seberang Ulu II District. The results of this study indicate that, on average, the results of the percentage analysis of the level of student's critical thinking skills in class X high school in Plaju District is $49.46 \%$, and Seberang Ulu II District is $56.52 \%$. Both the percentage of indicators critical thinking skills in Plaju and Seberang Ulu II District are in the medium category.
\end{abstract}

Keywords: Critical Thinking Skills, teacher questionnaire. 


\section{Introduction}

Education is a very important thing in life, and is useful for developing potential in individuals. One of the potential that can be developed that critical thinking skills. Khairunnisa (2016) states that hwa, critical thinking skills are thinking skills that involve cognitive processes in analyzing and evaluating and inviting students to think reflective of problems. The culmination of critical thinking skills is being able to make the best decisions from a number of alternative choices (Subali \& Suyata, 2012). Achieve optimal results in the learning process, it requires active thinking, this means that the optimal learning process requires critical thinking from the learner, because critical thinking is very important in the process of learning activities (Ahmatika, 2015).

Critical thinking is an important skill for students, so critical thinking should be one of the activities that must be developed and taught in each subject, because critical thinking skills not inherited from birth and do not develop naturally (Cahyono, 2017). Indicator Critical thinking skills used in this study refer to indicators (Facione, 2013), see Table 1.

Table 1. Critical Thinking Indicators

\begin{tabular}{cll}
\hline No & Skills & \multicolumn{1}{c}{ Sub Skills } \\
\hline 1 & Interpretation & \\
& & $\bullet$ Grouping \\
& & $\bullet$ Encode meaning \\
& & $\bullet$ Clear meaning \\
& & \\
& Analysis & \\
& & $\bullet$ Testing idea \\
& & \\
& & arguments \\
& & \\
& & Recognizing \\
& & statements
\end{tabular}

\begin{tabular}{cll}
\hline No & Skills & \multicolumn{1}{c}{ Sub Skills } \\
\hline 3 & Conclusion & \\
& & - Clear question \\
& & - Suspect alternative \\
& & - Assess the quality of \\
& & arguments made using \\
& & inductive or deductive \\
& & considerations
\end{tabular}

4 Evaluation

- Assess credibility of statements

- Assess the quality of arguments

- Assess the quality of arguments made using inductive or deductive considerations

5 Explanation

- Express results

- Support procedures

- Presenting arguments

6 Self-

Regulation

- Self-monitor

- Self-improvement

(Facione, 2013)

The six indicators of critical thinking skills in table 1, can be measured using instruments that have been developed through questions that have referred to critical thinking skills. This is in accordance with the opinion of Ennis (1993) that, critical thinking instruments can be developed and improved through predetermined aspects and indicators of critical thinking. people who have critical thinking can evaluate then conclude a matter based on a fact to make a decision (Dwijananti \& Yulianti, 2010). The instrument used to measure the critical thinking skills of class $\mathrm{X}$ high school students in Plaju and Seberang Ulu II Subdistricts, namely instruments in reasoned multiple choice questions. The use of reasoned multiple choice instruments is to overcome the shortcomings of the form of multiple choice questions that give students the 


\section{Putri et al.}

opportunity to guess the answer to the problem, besides the use of reasoned multiple choice instruments makes it easier to measure the abilities of students, especially critical thinking skills.

Sagap, Husain, \& Djirimu (2014) states that, the advantages of multiple choice questions reasoned that overcome the shortcomings of multiple choice questions. As well as having an advantage in detecting student misconceptions, because the teacher can see students' understanding, can minimize students' guessing answers and can determine the type of students' mistakes in a concept of understanding based on selected answers (Khotimah, 2014). Fadillah (2015) added that, to cover the shortcomings of multiple choice questions, the test questions in the form of reasoned multiple choices were used. This reason is to avoid students guessing and knowing the truth whether students really understand the questions or statements expressed and master the concepts.

\section{Research Method}

This research is a kind of quantitative descriptive research, data obtained from the sample population of the study were analyzed by looking for the percentage number. The population of this study were all high schools in the Plaju and Seberang Ulu II Districts.

The technique used in this study is purposive sampling technique. This sampling is based on the criteria used in the study which consists of Private High Schools and High Schools, state high school accreditation namely "A" and Private High School accreditation namely "B", the accreditation value of each Public High School is not less than 90 (> 90), and Private High School no more than 90 $(<90)$. The name of the SMA which is the sample of the researcher can be seen in
Table 2. The number of respondents in the study can be seen in Table 3 .

Table 2. Sample of this research

\begin{tabular}{ccccc}
\hline No & Nama Sekolah & Nilai & Kec. & Akr. \\
\hline 1 & SMA A & 97 & Plaju & A \\
2 & SMA B & 81 & Plaju & B \\
3 & SMA C & 94 & SU II & A \\
4 & SMA D & 85 & SU II & B
\end{tabular}

(BAN-SM, 2006)

$\mathrm{Kec}=$ Distric

$\mathrm{Akr}=$ Accreditation

SU II= Seberang Ulu II

Table 3. Number of respondents

\begin{tabular}{ccccc}
\hline No & Nama Sekolah & Kec. & PD & Guru \\
\hline 1 & SMA A & Plaju & 135 & 1 \\
2 & SMA B & Plaju & 23 & 1 \\
3 & SMA C & SU II & 96 & 1 \\
4 & SMA D & SU II & 21 & 1 \\
\hline & Jumlah & & 275 & 4 \\
\hline
\end{tabular}

$\mathrm{PD}=$ Students

The data instruments used in this study were questionnaires, interview sheets, observation sheets, documentation, and tests in the form of reasoned multiple choice instruments. The question instruments used in this study have been developed by Hidayat, Harfian, and Fadillah in 2018.

The data analysis technique used is quantitative descriptive analysis, which is by describing the results of the analysis of students critical thinking skills of grade $X$ high school in Plaju and Seberang Ulu II Districts. The results of the research data are obtained from the students' answer sheets, then analyzed by adding the scores according to the assessment rubric. The score obtained from all students in each sample of a high school school was combined based on the Districts of Plaju and Seberang Ulu II. Data from the results of research in Plaju District and Seberang Ulu II District were analyzed using the Microsoft Excel 2007. 
There are five categories in mastering critical thinking skills, namely very high, high, medium, low, and very low based (Azwar, 2014). The five categories of mastery of critical thinking skills are determined based on the formula adapted from Azwar (2014) (see table 4)

Table 4. Category of Students Critical Thinking Skills

\begin{tabular}{clr}
\hline No & \multicolumn{1}{c}{ Category } & Average Score (\%) \\
\hline 1 & Very High & $75,05<\mathrm{X}$ \\
2 & High & $58,35<\mathrm{X} \leq 75,05$ \\
3 & Middle & $41,65<\mathrm{X} \leq 58,35$ \\
4 & Low & $24,95<\mathrm{X} \leq 41,65$ \\
5 & Very low & $\mathrm{X} \leq 24,95$ \\
\hline
\end{tabular}

$\mathrm{X}=$ Average score obtained bystudents

The formula used to find the percentage of mastery of critical thinking skills of class X high school students in Plaju and Seberang Ulu II Subdistricts in this study was adapted from Purwanto (2006). The percentage is obtained by dividing the score on critical thinking skills, which are answered correctly by students with maximum scores on indicators of critical thinking skills. Ika J mathematically written as follows:

$$
\mathrm{NP}=\frac{\mathrm{R}}{\mathrm{SM}} x 100
$$

\footnotetext{
$\mathrm{NP}=$ Percent value

$\mathrm{R}=$ Score obtained from the indicators of critical thinking skills

$\mathrm{SM}=$ maximum score from the indicator of critical thinking skills

$100=$ Fixed number
}

\section{Results and Discussion}

Data from the research results used in this study were obtained from answer sheets for reasoned multiple choice questions. The reasoned multiple choice instrument was used to measure the critical thinking skills of class $\mathrm{X}$ high school students in Plaju and Seberang Ulu II Districts. Question instruments are distributed to students after students receive ecological material learning. Data from the results of this study were analyzed using the Microsoft Excel 2007 program . After the data were analyzed, then the percentage of scores obtained and matched with categories of mastery of critical thinking skills were examined in Table 4.

The percentage results showed that the two Plaju sub-districts were $49.46 \%$ with the medium category, and the Seberang Ulu II sub-district was $56.52 \%$ with the medium category. The results of the percentage of critical thinking skills of class X high school students in Plaju and Seberang Ulu II Districts, see in Figure 1.

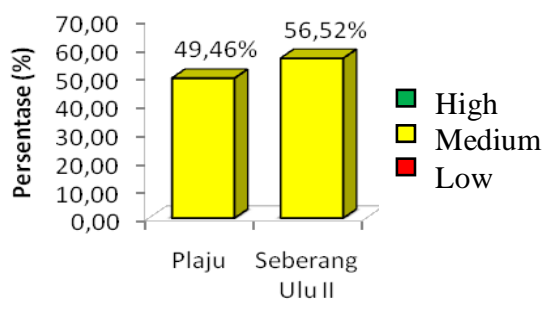

Figure 1. Percentage of indicators of students' critical thinking skills High school class $X$ in Plaju and Seberang Ulu II districts

The percentage results in Plaju Subdistrict, it can be seen that the mastery of indicators of critical thinking skills, on indicators interpreting is $51.79 \%$ medium category, indicators analyze $55.77 \%$ with moderate categories, indicators evaluating at $38.47 \%$ with low categories, indicators referring to $51.05 \%$ with the medium category, the indicator explains $48.87 \%$ with the medium category, and the selfregulation indicator is $59.28 \%$ with the high category. The results of the percentage of critical thinking skills of class X high school students in Plaju District, can be seen in Figure 2. 


\section{Putri et al.}

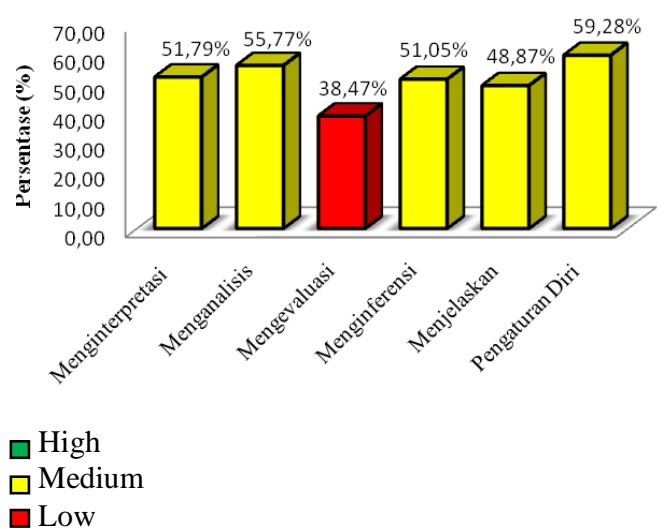

Figure 2. Percentage of indicators of critical thinking skills of class $\mathrm{X}$ high school students in Plaju District

Seen in Figure 2. Regarding the highest average percentage value, namely in the aspect of self-regulation amounting to $59.28 \%$ with a high category, and the lowest average percentage is the indicator evaluating at $38.47 \%$ with a low category.

Constraints experienced by high school teachers in Plaju Subdistrict in applying the measurement of critical thinking skills, which are constraints in making assessment sheets to measure the critical thinking skills of pe and students, because of the limited time that teachers have to make, this resulted in the need for alternative instruments to measure skills critical thinking, and limited knowledge possessed by high school students in Plaju Subdistrict, this statement was obtained from interviews, and high school teacher questionnaire sheets in Plaju District. The statement is in accordance with the observations of the implementation of the learning process, which is found that there are still students who are still less able to give an assessment and describe opinions on the material being studied. Limitations of knowledge possessed by students due to students who do not pay attention when the teacher is explaining the material being studied. This causes the low indicator to evaluate students, because in the learning process, the teacher provides guidance to students in explaining the material being studied, so that students become more understanding about the material being studied.

Based on the results of interviews with high school teachers in Plaju District regarding the causes of high indicators of self-regulation of students, namely because students pay attention to the explanation of the material delivered by the teacher. In addition, from learning resources in the form of books and the internet, and students are used to working on evaluating questions, and students can get information from their peers.

Self-regulating in learning is a process of self-learners who can set up and manage your thoughts, feelings, desires, and the action to be taken (Friskilia S \& Winata, 2018). One strategy applied in learning to optimize performance is learning based on selfregulation (Damayanti, 2015). Ahmar (2016) argues that, self-regulation is the skill of students to manage achievement strategies, determine targets, and think of everything related to achieving desired goals and ultimately able to evaluate their success in learning, thus causing them to have a strong drive to learn and actively participate in learning.

Istriyanti \& Simarmata (2014) states that self-regulation becomes a matter that needs to be considered in carrying out developmental tasks as a teenager. Students who try to regulate themselves or manage themselves as much as possible, will make students develop so that they reach the desired stage (Alfiana, 2013). Individual self-regulation activities involve setting attention, thoughts, behaviors and emotions simultaneously in an effort to design, control and direct selfbehavior to fit the goals to be achieved so that there is no gap between mindset and behavior (Ardina \& Kencana, 2013). 
Based on the results of high school teacher interviews in Plaju Subdistrict, the causes of low indicators evaluate students because students do not pay attention when the learning process takes place, and the limitations of students in utilizing learning resources. Arifin (2012) states that, evaluation is an activity of giving value and meaning rather than something. The purpose of evaluation in the learning process is to find out the effectiveness and efficiency of the learning system widely (Asrul, Ananda, \& Rosnita, 2014).

Evaluation of student achievement, divided into four. First formative evaluation, which is intended to improve the teaching and learning process, which is carried out by the teacher. Both summative evaluations, which are intended for the purpose of determining the numbers of progress or learning outcomes of students, are carried out by the teacher in a one-semester program. Third is placement evaluation, which is intended to place students in learning situations or educational programs that are in accordance with their abilities. The four diagnostic evaluations, which are intended to help solve learning difficulties experienced by certain students (Ahmad, 2015).

The way to improve critical thinking skills in evaluating learners' indicators is to improve the quality of learning, management of classroom management, and familiarize students with problem training, so that students are able to understand the material taught by high school teachers in Plaju District. the results of follow-up interviews with high school teachers in Plaju Subdistrict, on ways to improve evaluation skills, namely by giving training assignments in the form of evaluating, changing teaching methods by the teacher. The teacher must master the material taught, so that the material is conveyed well to students and the teacher must improve the mastery of management in the classroom.

The increase in the quality of learning can be achieved if the learning process in the class takes place well, efficiently and effectively. Improving student learning evaluation, it is necessary to prepare a test (Tabroni, 2007). Tests in the form of problem training by teachers for students is one of the activities of evaluating students, with the aim of exercising the ability of students to evaluate a given problem. Clarified by Arifin (2012) that, giving treatments such as daily meeting, final semester examinations, block examinations, written tests, oral tests, action tests, and so on are the basis of the part of the evaluation system itself in order to develop students' abilities.

Class management is a conscious effort to organize the activities of the teaching and learning process systematically, so that the conditions of the teaching and learning process run well and the goals can be achieved. Components of classroom management skills related to the creation, maintenance of optimal learning conditions consist of skills, responsiveness, dividing attention, and focusing group attention (Hilali, 2012).

The percentage results in Seberang Ulu II District, regarding mastery of indicators of critical thinking skills, on indicators interpreting $61.11 \%$ with high categories, indicators analyzing 58.88\% with high categories, indicators evaluating at $42.55 \%$ with medium categories, indicators inference of $64.96 \%$ with a high category, the indicator explained $59.16 \%$ with a high category, and the selfregulation indicator was $65.81 \%$ with a high category. The results of the percentage of critical thinking skills of class X high school students in Seberang Ulu II District, see Figure 3. 


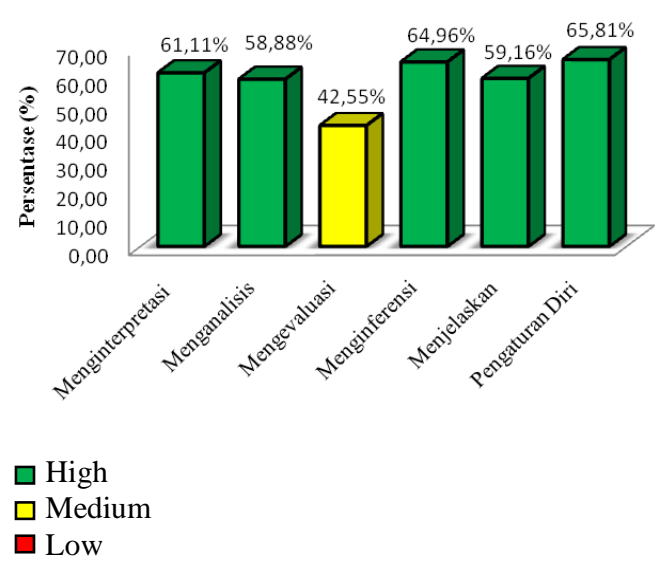

Figure 3. Percentage of indicators of critical thinking skills of class X high school students in Seberang Ulu II District

The percentage of indicators of critical thinking skills in Seberang Ulu II Subdistrict, which has the highest average percentage value, is on the self-regulation indicator of $65.81 \%$ with a high category, and the lowest average value of the indicator evaluates at $42.55 \%$ with medium category.

Based on the results of interviews with teachers in Seberang Ulu II Subdistrict, regarding the problems experienced by high school teachers in applying measurements of critical thinking skills namely students who pay less attention to the learning process, and lack of ability of students to analyze, further understanding is needed to improve students' critical thinking skills.

Based on the observation results of the learning process, it was found that students were still not able to give an opinion about the conclusions of the learning activities, even though high school teachers in Seberang Ulu II Subdistrict had explained the material taught in the classroom, so that the students were still guided by the teacher so participants students understand the material learned, are able to give opinions about problems, and draw concepts or draw conclusions from the results of learning activities. Based on the results of high school teacher interviews in Seberang Ulu II Subdistrict, the cause of the high self-regulation indicators possessed by students is the high level of understanding, experience, and breadth of learning resources possessed by students.

Students who have higher selfregulation, also critical thinking skills (Ahmar, 2016). Kusaeri \& Mulhamah (2016) states that, metacognition, motivation, and behavior as aspects of self-regulation contribute significantly to student achievement. Students who utilize metacognition, motivation, and behavior within themselves will be able to understand their abilities.

The skills of students regulating themselves in the learning process, are important activities in the learning process of students (Arjanggi \& Suprihatin, 2010). Self regulation plays an important role in achieving students' learning goals, especially in lessons that are classified as difficult and require high analysis. Self-regulation is one of the main drivers of human personality, through self-regulation, students will be able to achieve optimal achievements during the education process (Hidayat, 2013).

According to Alfiana (2013), that the person responsible for carrying out the task can make the person have a separate training to regulate themselves, so that the regulation of that person develops. That is, the training of students in organizing themselves according to the activity schedule on a regular basis can develop indicators of self-regulation. This statement is in accordance with Mukhid (2008) that, the characteristic of learners self-regulated learning is that they see themselves as agents of their own behavior, they believe learning is a proactive process, they motivate 
themselves and use strategies i-strategies that enable them to improve their desired academic results.

Based on the results of interviews with high school teachers in the Seberang Ulu II sub-district, the cause of the low indicator evaluates the participants because it does not pay attention when the learning process is direct, and the limitations of participants utilize learning resources. Mahirah (2017) states that e valuation is defined as a systematic process for determining something value (provisions, activities, decisions, performance, processes, people, objects and others) based on certain criteria through assessment. Evaluation is the skill to find and prove the fault of a problem (Shanti, Sholihah, \& Martyanti, 2017). The purpose of evaluation is to determine quality rather than something, especially with regard to values and meaning (Arifin, 2012).

Based on the results of follow-up interviews with high school teachers in Seberang Ulu II Subdistrict to improve students' critical thinking skills on indicators evaluating students namely by training questions or question and answer, holding group learning between friends to share information, and improve classroom management.

Sujati (2006) explains that, the purpose of class management is to create optimal classroom conditions for the implementation of learning. a teacher can only be said to have carried out learning activities, if in students the behavior changes occur as a result of these activities. This means that the learning process has a positive impact on the development of students.

Apart from managing the class, the teacher also gives treatment to students to find out whether students have understood the material being taught, giving the treatment in the form of a practice test test sheet. Arifin (2012) states that, giving treatments such as daily tests, end of semester exams, block exams, bills, written tests, oral tests, action tests, and so on are the basis of part of the evaluation system. Enhancing evaluation of learners, necessary preparation of the test (Tabroni, 2007).

The results of the discussion of this study indicate the inability of students, to provide assessment arguments and measurement of the results of learning activities on the material taught, this is because students who do not pay attention when the teacher or classmates are explaining the material being studied, and lack of interest learn from the students themselves. Causing the value on the indicators of critical thinking skills evaluating the students of Class X High School in Plaju and Seberang Ulu II Subdistricts to be low.

These conditions can be overcome by the ability of the teacher in managing the class, so that students can be interested in paying attention to the teacher or friend when explaining the material being studied, so that students can understand the material being studied. Coupled with the provision of teacher treatment of students, to find out until where the understanding of students in understanding the material that has been studied in the form of problem practice tests. This illustrates the ability of students to evaluate can increase.

Students' critical thinking skills can be improved from the way they learn, if the way of learning is in accordance with the personality of the students then the learning outcomes will be optimal, if not appropriate then the learning outcomes will occur otherwise. Like the research conducted by Rokayana \& Efendi (2017) which states that, a person's learning style influences his critical thinking skills. 


\section{Putri et al.}

\section{Conclusion}

Based on the result and discussion, it can be conclude that the results of the percentage analysis of the mastery of critical thinking skills of class $\mathrm{X}$ high school students in Plaju district, the highest indicator is that there are $59.28 \%$ self-regulation indicators with high categories, and the lowest indicator is evaluating $38.47 \%$ in the low category. The results of the percentage analysis of the mastery of critical thinking skills of class X high school students in Seberang Ulu II district, the highest indicator is that there are $65.81 \%$ self-regulation indicators with a high category, and the lowest indicator on the indicator evaluates $42.55 \%$ with the moderate category.

Suggestions that can be submitted based on the results that the teachers and schools are advised to train and improve students' critical thinking skills. The next researcher is advised to conduct research on indicators of critical thinking skills based on other experts, and this research is expected to be a reference for future researchers.

\section{References}

Ahmad, N. (2015). Buku Ajar Evaluasi Pembelajaran. Yogyakarta: Interpena Yogyakarta.

Ahmar, D. S. (2016). Hubungan Antara Regulasi Diri dengan Kemampuan Berpikir Kreatif dalam Kimia Peserta Didik Kelas XI IPA SeKabupaten Takalar. Jurnal Sainsmart, Hal: 7-23.

Ahmatika, D. (2015). Peningkatan Kemampuan Berpikir Kritis dengan Pendekatan Inquiry/Discovery. Jurnal Euclid , 3(1), 394-403.

Alfiana, A. D. (2013). Regulasi Diri Mahasiswa Ditinjau Dari
Keikutsertaan Dalam Organisasi Kemahasiswaan. Jurnal Ilmiah Psikologi Terapan , 1(2), Hal: 245259.

Ardina, P. R., \& Kencana, W. D. (2013). Pengaruh Regulasi Diri terhadap Prokrastinasi Akademik pada Siswa SMA. Perspektif Ilmu Pendidikan , 30(2), 67-76.

Arifin, Z. (2012). Evaluasi Pembelajaran (Edisi Revisi). Jakarta: Direktorat Jenderal Pendidikan Islam Kementrian Agama.

Arjanggi, R., \& Suprihatin, T. (2010). Metode Pembelajaran Tutor Teman Sebaya Meningkatkan Hasil Belajar Berdasarkan Regulasi Diri. Makara, Sosial Humaniora , 14(2), Hal: 91-97.

Asrul, Ananda, R., \& Rosnita. (2014). Evaluasi Pembelajaran. Bandung: Ciptapustaka Media.

Azwar, S. (2014). Penyusunan Skala Psikologi. Yogyakarta: Pustaka Pelajar.

BAN-SM. (2006). Hasil Akreditasi SMA/MA Kota Palembang. Palembang: Dinas Pendidikan Palembang.

Cahyono, B. (2017). Analisis Keterampilan Berpikir Kritis dalam Memecahkan Masalah Ditinjau Perbedaan Gender. Aksioma, Hal: 50-64.

Damayanti, E. (2015). Peran Belajar Berdasar Regulasi Diri dan Penyesuaian Diri terhadap Prestasi Belajar Siswi Madrasah Tsanawiyah Muallimat Yogyakarta. Jurnal Biotek , 2(2), 54-69.

Dwijananti, P., \& Yulianti, D. (2010). Pengembangan Kemampuan Berpikir Kritis Mahasiswa Melalui Pembelajaran Problem Based INstruction Pada Mata Kuliah Fisika Lingkungan. Jurnal Pendidikan Fisika Indonesia, Hal: 108-114. 
Ennis, R. H. (1993). Critical Thinking Assesment. Theory into Pratice, Hal: 179-186.

Facione, P. A. (2013). Critical Thiking: What It Is and Why It Count . Millbrae, CA: Measured Reason and The Caifornia Academic Press.

Fadillah, E. N. (2015). Pengembangan Instrumen Penilaian Biologi untuk Mengukur Keterampilan Proses Sains dan Keterampilan Berpikir kritis Siswa SMA Kelas X Pada Materi Ekologi. Yogyakarta: Universitas Negeri Yogyakarta.

Friskilia S, O., \& Winata, H. (2018). Regulasi Diri (Pengaturan Diri) Sebagai Determinan Hasil Belajar Siswa Sekolah Menengah Kejujuran. Jurnal Pendidikan Manajemen Perkantoran , 1(2), Hal: 37-44.

Hidayat, A. F. (2013). Hubungan Regulasi Diri dengan Prestasi Belajar Kalkulus II Ditinjau dari Aspek Metakognisi, Motivasi, dan Perilaku. Jurnal Elektronik Pendidikan Matematika Tadulako, 01(01), Hal: 1-8.

Hilali, H. E. (2012). Pentingnya Pengelolaan Kelas dalam Pembelajaran. Edu-Bio , 129-136.

Istriyanti, N. L., \& Simarmata, N. (2014). Hubungan Antara Regulasi Diri dan Perencanaan Karir pada Remaja Putri Bali. Jurnal Psikologi Udayana , 1(2), 301-310.

Khairunnisa. (2016). Analisis Kemampuan Berpikir Kritis Siswa Kelas IX SMPN 3 Paringin pada Mata Pelajaran IPA. Prosiding Seminar Nasional Pendidikan IPA , 179-186.

Khotimah, F. N. (2014). Identifikasi Miskonsepsi Siswa pada Konsep Archaebacteria dan Eubacteria dengan Menggunakan Tes Diagnostik Pilihan Ganda. Jakarta: UIN Syarif Hidayatullah.
Kusaeri, \& Mulhamah, U. N. (2016). Kemampuan Regulasi Diri Siswa dan Dampaknya Terhadap Prestasi Belajar Matematika. Jurnal Review Pembelajaran Matematika , 1(1), Hal: 31-42.

Mahirah, B. (2017). Evaluasi Belajar Peserta Didik (Siswa). Jurnal Idaarah , 1(2), Hal: 257-267.

Mukhid, A. (2008). Strategi Self Regulated Learning. Tadris , 3(2), 222-239.

Purwanto, N. (2006). Prinsip-Prinsip dan Teknik Evaluasi Pengajaran. Bandung: Remaja Rosdakarya.

Rokayana, N. W., \& Efendi, N. (2017). Analisis Keterampilan Berpikir Kritis Siswa SMP pada Mata Pelajaran IPA Ditinjau dari Gaya Belajar Visual. Science Education Journal , 1(2), 84-91.

Sagap, Husain M.P, S. N., \& Djirimu, M. (2014). Analisis Pemahaman Konsep Biologi Menggunakan Pilihan Ganda Beralasan dalam Materi Pokok Sel pada Siswa Kelas XI IPA SMA Negeri 1 Dampal Selatan. Jurnal e-Jipbiol , 2(3), 18.

Shanti, W. N., Sholihah, D. A., \& Martyanti, A. (2017). Meningkatkan Kemampuan Berpikir Kritis Melalui Problem Posing. Literasi, Hal: 49-59.

Subali, B., \& Suyata, P. (2012). Pengembangan Item Tes Konvergen dan Divergen. Yogyakarta: Pustaka Indonesia.

Sujati. (2006). Manajemen Kelas yang Efektif dalam Pembelajaran. Dinamika Pendidikan , 109-123.

Tabroni. (2007). Upaya Menyiapkan Pendidikan yang Berkualitas. Jakarta: Gaung Persada. 